\title{
MULTINOMIAL LOGIT MODEL OF HOUSING DEMAND IN POLAND
}

\author{
Michał Głuszak, PhD. \\ Department of Economics for Real Estate and Investment Process \\ Cracow University of Economics \\ e-mail: gluszakm@uek.krakow.pl
}

\begin{abstract}
When compared to mature housing markets, little has been done to understand the nature of demand on emerging housing markets in Central and Eastern Europe and to develop testable models for postsocialist economies. With the exception of BAZYL (2009) and GŁUSZAK (2010), there is hardly any econometric evidence on factors behind housing tenure choices in Poland. The article focus mainly on: permanent (and current) income, household structure, lifecycle, and differences between local market characteristics. In the research, multinomial logistic regression is used to analyze factors that increase the probability of young households becoming homeowners.

The major objectives of the study are:

1) estimation of housing demand at household level,

2) discussion of factors increasing the probability of becoming homeowner,

3) discussion of advantages and limitations of using classical qualitative response models to estimate housing demand.

The research is based on latest European Union Statistics on Income and Living Conditions (EUSILC) 2007-2010 dataset (panel of approx. 4,500 households).
\end{abstract}

Key words: homeownership, multinomial logit, housing demand, tenure choice.

JEL Classification: D12, R21.

Citation: Głuszak M., 2015, Multinomial Logit Model of Housing Demand in Poland, Real Estate Management and Valuation, Vol. 23, No. 1, pp. 84-89.

DOI: 10.1515/remav-2015-0008

\section{Introduction}

Economic literature is abundant in empirical research on housing demand. There is a significant body of works on housing investment at the household level, with the majority of researchers focusing on explaining factors increasing the chances of becoming a homeowner (HENDERSON and IOANNIDES 1983; Chung and HAurin 2002; ORTOlO-MAGNE and RADY 1999; KAN 2000). Most of these studies have been conducted in mature market conditions and do not reflect the housing context of emerging markets, where empirical evidence is scarce. Results from previous studies conducted in Poland (BAZYL 2009, GŁUSZAK 2010; STRĄCZKOWSKI 2009; AUGUSTYNIAK et al. 2013) suggest that the age of the head of a household is one of the factors which most strongly influence the probability of choosing a given form of tenure to the occupied residential unit. The older the household, the bigger the likelihood that it will possess its own flat, ceteris paribus. On the other hand, with other factors remaining unchanged, the likelihood of living with parents, which is very high among young households (particularly with a small number of members, not possessing children) decreases quickly with age, just like the probability of renting a residential unit on the free market. A higher rate of homeownership can have economic (via wealth effect, see ŻELAZOWSKI 2009) and social (DIPASQUALE and GLEASER 1999; HAURIN et al. 2002) consequences. 
The countries of Central and Eastern Europe share a recent past of centrally-controlled economies. Compared to their EU 15 counterparts, CEE countries, including Poland, clearly lag behind in several indicators of housing market activity. Both the average living space per person and dwelling stock per one thousand inhabitants indicate quantitative and qualitative gaps between Western and Eastern European countries. Economic and financial factors, such as GDP per capita, salaries, and the mortgage debt ratio show substantial areas for growth as well, but they also tend to reveal cyclical behavior (TROJANEK 2011).

According to EUROSTAT, more than $70 \%$ of the European Union population lived in owneroccupied housing in 2011. Approximately 43\% of the population owned a home without a loan or mortgage. Meanwhile $18.0 \%$ of the population of the $28 \mathrm{EU}$ member states were renting their housing at a market price rent, and more than $11 \%$ were renting it at a reduced rate or had free accommodation.

It should be noted that the share of owner-occupied dwellings in the European Union ranged from $53 \%$ in Germany to $96.6 \%$ in Romania. In Switzerland, the proportion of people who lived in rented dwellings outweighed those living in owner-occupied dwellings, as some $56.1 \%$ of the population were tenants. An overview of housing statistics has been presented in Fig. 1.

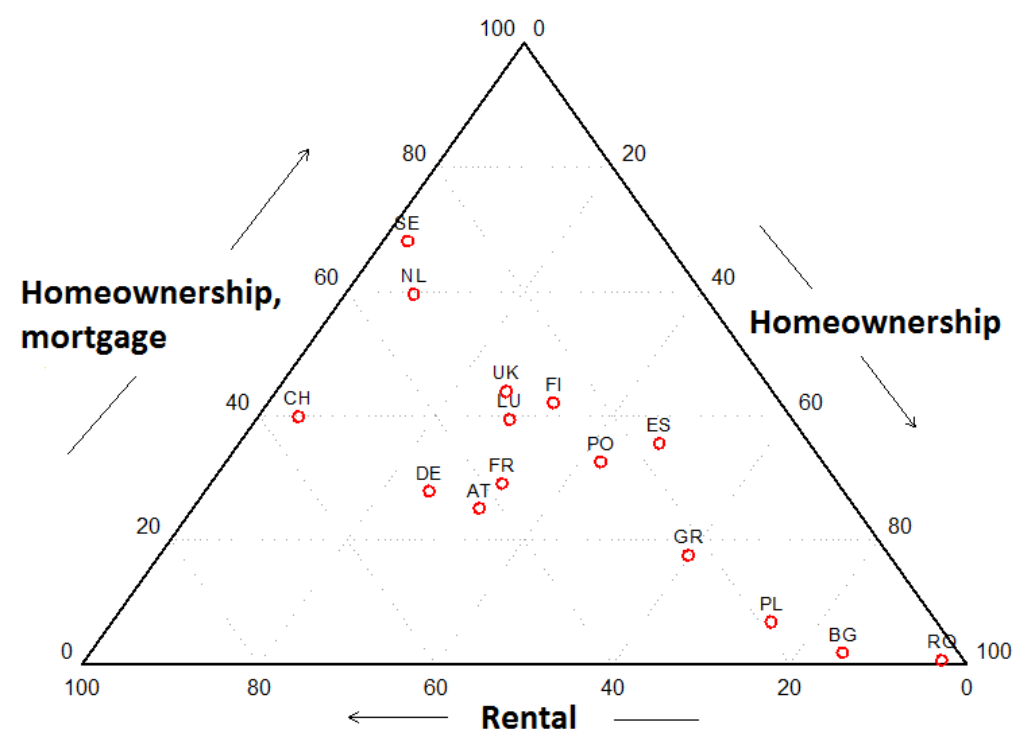

Fig. 1. Housing tenure status in Europe in 2010. Source: own study based on Eurostat

The majority of households in Poland lived in owner-occupied housing units (to be precise $82 \%$ of the population). The rental market in Poland is relatively underdeveloped (approximately 2\% of households rented housing units at market rate) compared to some Western European economies, such as in Germany $(40 \%)$, Sweden $(30 \%)$ or the Netherlands (32\%). It should be noted, that the law on housing rental (including rent control and tenant protection) has changed frequently over the last decade in Poland, thus hindering the development of a mature rental market. Market rental is, to some extent, based upon dubious practices, resulting in tax evasion.

\section{Data and methods}

To model the tenure choice, a panel of microdata from the European Union Survey on Incomes and Living Conditions 2006-2010 (EUROSTAT 2010) was used. The EU-SILC is a rotational panel, based on a representative sample of households in the European Union. The survey has been carried out in EU member states since 2003, although at first, only in six countries (Poland joined in 2005). A panel data from the EU-SILC allows for cross-sectional and longitudinal data analysis of incomes, poverty, social exclusion and living conditions in the European Union. In the study, a subsample of the EU-SILC dataset was used (data on Poland from 2007 to 2010), acquired from Central Statistical Office of Poland.

The aim of the study is to explore the factors behind the housing investments of Polish households. In order to explore the differences in housing tenure status and explain the socio-economical 
covariates related to becoming a homeowner, a multinomial logistic regression model was used. In the study, we assumed that housing status is not dichotomous - simply being a homeowner or not. EUSILC data reports four basic housing tenures. A household can: own a property (be a homeowner), rent a housing unit at market rate, rent a housing unit at reduced rate (usually from public stock), or have a free accommodation (usually living with family). The dependant variable is qualitative, thus the study employed a model for a qualitative response variable.

To explore the major factors influencing the probability of selecting tenure alternatives a multinomial logit model (MLM) was estimated. For $k$ categorical outcomes (1 being a base outcome), the probability of observing outcome $i$ is (GREEN 2012, pp. 765-766):

$$
\operatorname{Pr}\left(y_{j}=i\right)=\left\{\begin{array}{l}
\frac{1}{1+\sum_{m=2}^{k} \exp \left(x_{j} \beta_{m}\right)}, i=1 \\
\frac{\exp \left(x_{j} \beta_{i}\right)}{1+\sum_{m=2}^{k} \exp \left(x_{j} \beta_{m}\right)}, i>1
\end{array}\right.
$$

The multinomial logit model is a standard econometric for qualitative dependant variables and can be estimated using maximum likelihood.

\section{Modeling housing tenure choice in Poland}

\subsection{Variables in the model}

Four housing alternatives are distinguished in the study as the dependent variable of the multinomial logit model. They are defined on the basis of the analysis of possible tenure types:

1) ownership,

2) rental,

3) non-market rental,

4) living with family.

On the other hand, on the basis of literature review and previous explorative research (see GLUSZAK 2010), several independent variables were selected to explain tenure choices made by households. The variable selection includes demographic and socioeconomic variables, as well as a dummy variable that codes the size of the housing market the household is living in. An overview of explanatory variables has been presented in Table 1 .

Table 1

Explanatory variables

\begin{tabular}{|c|c|}
\hline Variable & Description \\
\hline loc1 & $\begin{array}{l}1 \text { if the household lives in a city with a population larger than } 499 \\
\text { thousands inhabitants, } 0 \text { otherwise; is a base category in the model }\end{array}$ \\
\hline loc2 & $\begin{array}{l}1 \text { if the household lives in a city with a population between } 200 \text { and } \\
499 \text { thousand inhabitants, } 0 \text { otherwise }\end{array}$ \\
\hline loc3 & $\begin{array}{l}1 \text { if the household lives in a city with a population between } 100 \text { and } \\
199 \text { thousand inhabitants, } 0 \text { otherwise }\end{array}$ \\
\hline loc4 & $\begin{array}{l}1 \text { if the household lives in a city with a population between } 20 \text { and } 99 \\
\text { thousand inhabitants, } 0 \text { otherwise }\end{array}$ \\
\hline loc5 & $\begin{array}{l}1 \text { if the household lives in a city with a population smaller than } 20 \\
\text { thousand inhabitants, } 0 \text { otherwise }\end{array}$ \\
\hline loc6 & 1 if the household lives in a rural area, 0 otherwise \\
\hline age & Age of the head of the household (years) \\
\hline eincome & Household's equivalised disposable income (in euros) \\
\hline size & Household size (number of members) \\
\hline
\end{tabular}


A series of dummy variables was used to control for the size of the residential area (loc1-loc6). The indicators of a family lifecycle are the age of the person responsible for economic decisions (head of family) - age, and the number of household members - size. The eincome variable stands for so-called equivalised disposable income, which is the total income, after tax and other deductions, that is available to a household (divided by the number of household members, who are additionally weighted according to their age).

\subsection{Results and discussion}

Although McFadden's R2 indicates mediocre fit to the data (Pseudo R2 ranging from 0.1844 in 2007 to only 0.0982 in 2010), this is, to some extent, typical of models based on survey data. On the other hand, the result may stem from the omission of some explanatory variables in the model.

Table 2

Multinomial logit model estimation results (dependant variable is housing tenure)

\begin{tabular}{|c|c|c|c|c|}
\hline & $\begin{array}{c}\text { MOD } \\
2007\end{array}$ & $\begin{array}{c}\text { MOD } \\
2008\end{array}$ & $\begin{array}{c}\text { MOD } \\
2009\end{array}$ & $\begin{array}{c}\text { MOD } \\
2010\end{array}$ \\
\hline Ownership & \multicolumn{4}{|c|}{ Base alternative } \\
\hline \multicolumn{5}{|c|}{ Rental at market rent } \\
\hline Loc2 & -0.0934 & $-0.745^{* *}$ & $-0.922^{* * *}$ & $-0.817^{\star *}$ \\
\hline Loc3 & 0.160 & $-0.849^{* *}$ & $-0.688^{*}$ & $-1.013^{\star *}$ \\
\hline Loc4 & $-0.843^{* *}$ & $-1.182^{* * *}$ & $-1.248^{\star * *}$ & $-0.919^{* * *}$ \\
\hline Loc5 & $-0.888^{*}$ & $-1.471^{* * *}$ & $-1.198^{* * *}$ & $-1.100^{* * *}$ \\
\hline Loc6 & $-3.054^{* * *}$ & $-3.178^{* * *}$ & $-3.307^{* * *}$ & $-2.692^{* * *}$ \\
\hline age & $-0.0603^{* * *}$ & $-0.0741^{* * *}$ & $-0.0835^{* * *}$ & $-0.0810^{* \star *}$ \\
\hline eincome & -0.0000666 & $-0.000103^{\star * *}$ & $-0.000190^{* * *}$ & $-0.000135^{\text {***}}$ \\
\hline size & $-0.508^{* * *}$ & $-0.423^{* * *}$ & $-0.301^{* * *}$ & $-0.254^{* * *}$ \\
\hline constant & $2.526^{* \star *}$ & $3.492^{* \star *}$ & $4.040^{* \star *}$ & $2.866^{* * *}$ \\
\hline \multicolumn{5}{|c|}{ Rental at reduced rent } \\
\hline Loc2 & -0.303 & -0.637 & -0.423 & -0.629 \\
\hline Loc3 & -0.0222 & 0.278 & 0.335 & 0.0307 \\
\hline Loc4 & -0.585 & -0.532 & $-1.115^{* *}$ & -0.360 \\
\hline Loc5 & $-1.847^{* *}$ & -0.474 & $-0.889^{*}$ & -0.104 \\
\hline Loc6 & $-2.504^{* * *}$ & $-1.511^{* * *}$ & $-2.059^{* * *}$ & $-1.524^{* * *}$ \\
\hline age & $-0.0628^{* * *}$ & $-0.0566^{* * *}$ & $-0.0601^{* * *}$ & $-0.0445^{\star \star *}$ \\
\hline eincome & $-0.000382^{\text {*** }}$ & -0.0000471 & $-0.000106^{* * *}$ & $-0.000125^{* *}$ \\
\hline size & -0.0705 & $-0.352^{* * *}$ & $-0.170^{*}$ & -0.144 \\
\hline constant & $1.722^{*}$ & 0.546 & $1.105^{*}$ & -0.329 \\
\hline \multicolumn{5}{|c|}{ Free accomodation } \\
\hline Loc2 & 0.249 & 0.0327 & -0.109 & -0.208 \\
\hline Loc3 & 0.295 & 0.00680 & 0.0216 & 0.217 \\
\hline Loc4 & $-0.425^{* *}$ & $-0.543^{\star * *}$ & $-0.721^{* * *}$ & $-0.478^{\star \star *}$ \\
\hline Loc5 & $-0.958^{* * *}$ & $-1.193^{* * *}$ & $-1.076^{* * *}$ & $-0.559^{* * *}$ \\
\hline Loc6 & $-2.718^{* * *}$ & $-2.639^{* * *}$ & $-2.663^{* * *}$ & $-1.647^{\star * *}$ \\
\hline age & $-0.0114^{* * *}$ & $-0.0121^{* * *}$ & $-0.0147^{* * *}$ & $-0.0165^{* * *}$ \\
\hline eincome & $-0.0000765^{* \star *}$ & $-0.0000671^{* * *}$ & $-0.0000736^{* * *}$ & $-0.000176^{\text {***}}$ \\
\hline size & $-0.0783^{* *}$ & $-0.101^{* * *}$ & $-0.120^{\star * *}$ & $-0.103^{* * *}$ \\
\hline constant & $1.510^{* * *}$ & $1.586^{* * *}$ & $1.816^{* * *}$ & $1.150^{* * *}$ \\
\hline $\bar{N}$ & 3830 & 7281 & 9968 & 9322 \\
\hline Pseudo R2 & 0.1844 & 0.1715 & 0.1644 & 0.0982 \\
\hline
\end{tabular}

Source: own study, Loc1 set as the base category. 
Four multinomial logistic regression models were estimated in the study - one for each year the survey was conducted (MOD2007, MOD2008, MOD2009, MOD2010). The main reason was to ensure robustness of the results.

The chance to observe households renting housing units at market rate in comparison with possessing their own flat is definitely greater in big cities than in the countryside, ceteris paribus. Analogously, the bigger the place of residence, the lower the probability of living with family in comparison with possessing one's own flat (young households tend to migrate to bigger cities, so they can no longer stay with their parents). In comparison with households in major cities, residents of smaller rural and urban areas are less likely to rent a residential unit at reduced rate (smaller stock of social housing). All the above dependencies are probably, to a great extent, the product of the accessibility of individual housing options; for example, in the country the supply of company premises, social premises, as well as premises intended for rental is limited.

The likelihood that a household will rent a house on the free market or live with family instead of possessing real estate decreases with age. The percentage of households renting a flat on the free market in comparison with those possessing one is dramatically decreased when the size of the household increases. This regularity is quite intuitive - a large number of family members requires a bigger flat, the rental of which is expensive (which makes this alternative not profitable when compared to the purchase of a flat and the repayment of mortgage).

Higher equivalised disposable income significantly decreases the probability of renting a flat (according to both market and non-market principles) as opposed to being a homeowner, ceteris paribus. This is also an intuitive regularity. Higher income usually translates into an improvement of the economic situation, the confirmation of which is certainly one's own residential unit. Moreover, higher monthly earnings increase housing affordability and enable access to a mortgage (which is particularly important for young households which have not yet accumulated the necessary capital to purchase a dwelling).

Thanks to the panel structure of the data, it is possible to examine transitions between different housing tenure probabilities. The question to be answered here was: are homeowners likely to change their status to another (either rental or free accommodation)? The results can be found in Table 3.

Table 3

Transition probabilities between different housing tenures

\begin{tabular}{llllll}
\hline Tenure status & Ownership & $\begin{array}{l}\text { Rental at } \\
\text { market rent }\end{array}$ & $\begin{array}{l}\text { Rental at } \\
\text { reduced rent }\end{array}$ & $\begin{array}{l}\text { Free } \\
\text { accomodation }\end{array}$ & Total \\
\hline Ownership & 97.85 & 0.02 & 0.02 & 2.12 & 100.00 \\
Rental at market rate & 6.57 & 70.71 & 4.55 & 18.18 & 100.00 \\
Rental at reduced rate & 1.20 & 10.84 & 71.08 & 16.87 & 100.00 \\
Free accomodation & 10.70 & 0.46 & 0.50 & 88.34 & 100.00 \\
\hline Total & 68.52 & 1.66 & 0.85 & 28.97 & 100.00 \\
\hline
\end{tabular}

Source: own study.

Over the four-year period covered by the study (2007-2010), only $2.2 \%$ of homeowners changed their tenure status, usually returning to free accommodation (in most cases, this probably means returning to living with their parents). In contrast, housing tenure for renters was more likely to change (approximately $29 \%$ of households renting a dwelling in 2007 changed their status, although some changed their housing status within the rental sector - from market rent to reduced rent, and vice versa).

It is interesting to note that $88 \%$ of households residing in rent-free accommodation at the start did not change their status in the study period. Only $1 \%$ of the group became renters, while $11 \%$ invested in their own housing units, assuming the status of homeowners. This too can be easily explained. Some young households tend to live with their parents (free of charge) until they can afford to buy their own housing (saving money they would otherwise spend on rent). 


\section{Conclusions}

The results suggest that tenure status in Poland is mainly influenced by lifecycle - older households are more likely to own, but also to be non-market renters. The major reason behind this is the accumulation of capital. Residing in rent-free accommodation is popular among young households, especially in rural areas, with the number of households in this group also decreasing with age. The better the economic situation of a household (equivalised disposable income), the higher the likelihood of becoming a homeowner; one of the reasons behind this is reduced borrowing constraint. Another interesting conclusion is that transition between tenure statuses is less probable when the household is a homeowner. Homeowners rarely change their housing to rental. Moreover, significant differences in housing tenure were observed for different housing markets (the major factor being the size of the areas of residence). The rental sector in Poland is thin, and practically limited to major agglomerations; in small cities and villages, housing rental is not likely to be encountered. As the panel structure of the dataset was not exploited to its full extent, one obvious direction for future research is to use a panel logit model (fixed effect and random effect), also taking into account the changing conditions on the housing market (housing policy effects, the relative cost of owning and renting a dwelling, property taxation).

\section{Acknowledgement}

The author would like to acknowledge the financial support of: (1) the National Science Center of Poland under the OPUS grant (DEC-2011/03/B/HS4/01160) and (2) the Cracow University of Economics under the grant for young researchers (122/KENiPI/2/2012/MN/105)

\section{References}

AugustyniaK H., LaszeK J., OlszewsKi K., WAsZcZuK, J., 2013, To Rent or to Buy - Analysis of Housing Tenure Choice Determined by Housing Policy, National Bank of Poland Working Paper No. 164.

BAZYL M., 2009, Factors Influencing Tenure Choice in European Countries, Central European Journal of Economic Modelling and Econometrics, No. 1(4), pp. 371-387.

CHUnG, E., HAURIN D., 2002, Housing Choices and Uncertainty: the Impact of Stochastic Events, Journal of Urban Economics 52, pp. 193-216.

DiPASQuale D., Glaeser E., 1999, Incentives and Social Capital: Are Homeowners Better Citizens? Journal of Urban Economics, No. 45 (2), pp. 354-384.

EU-SILC, European Union Statistics on Income and Living Conditions (2007-2010), EuROSTAT.

GŁUSZAK M., 2010, Cechy gospodarstw domowych a sposoby zaspokajania potrzeb mieszkaniowych w Polsce (Characteristics of Households and Their Tenure Status in Poland), Zeszyty Naukowe Uniwersytetu Ekonomicznego w Krakowie, No. 822, pp. 31-46.

GREENE W., 2012, Econometric Analysis. 7th ed., Upper Saddle River, NJ: Prentice Hall

Haurin D., Parcel T., Haurin J., 2002, Does Homeownership Affect Child Outcomes?, Real Estate Economics, No. 30 (4), pp. 635-666.

HENDERSON J., IOANNIDES Y., 1983, A Model of Housing Tenure Choice, The American Economic Review, No. 73 (1), pp. 98-113.

Housing Conditions, 2011, EUROSTAT, available at: http:/ / epp.eurostat.ec.europa.eu/statistics_explained/index.php/Housing_conditions [Accessed: 15.02.2013]

KAN, K., 2000, Dynamic Modeling of Housing Tenure Choice, Journal of Urban Economics, No. 48 (1), pp. 46-69.

Ortalo-Magne, F., Rady S., 1999, Boom In, Bust Out: Young Households and the Housing Price Cycle, European Economic Review, No. 43(4-6), pp. 755-766.

STRĄCZKOWSKI Ł., 2009, Motywy zakupu mieszkań w świetle badań nabywców na lokalnym rynku mieszkaniowym w Poznaniu (Motives Behind the Purchase of Flats in the Light of Buyers' Research on the Housing Market in Poznan), Journal of the Polish Real Estate Scientific Society, No. 17(2), pp. 45-56.

TROJANEK R., 2011, Wptyw wahan koniunkturalnych na lokalne rynki mieszkaniowe (Influence of the Business Cycle on the Housing Market), Journal of the Polish Real Estate Scientific Society, No. 19(1), pp. 81-94.

ŻELAZOWSKI K., 2009, Efekt majątkowy nieruchomości (Housing Wealth Effect), Journal of the Polish Real Estate Scientific Society, No. 17(2), pp. 81-94. 